8. Sharma, D.P. 1986. Text Book of Algae. Tata McGraw-Hill Publishing Company, New Delhi.

9. Schopf, T.W. and M.R. Walter. 1982. Pp.543-564. In:Carr, N.G. and Whitton, B.A. (eds.) The Biology of the Cyanobacteria. The University of California Press, Berkelely, California.

10. Woodmansee, R.E. 1979. Factors influencing input and output of nitrogen in grasslands. Pp. 117-134. In: French, N.R. (ed.). Perspectives in Grassland Ecology. Springer-Verlag, New York.

\title{
NEW VASCULAR PLANT FINDS AT THE RENDEK ELM FOREST
}

DIANA BIZECKI ROBSON, 811 Avenue E North, Saskatoon, SK S7L 1 S7 and VERN HARMS, 212-115 Keevil Crescent, Saskatoon, SK S7N 4P2

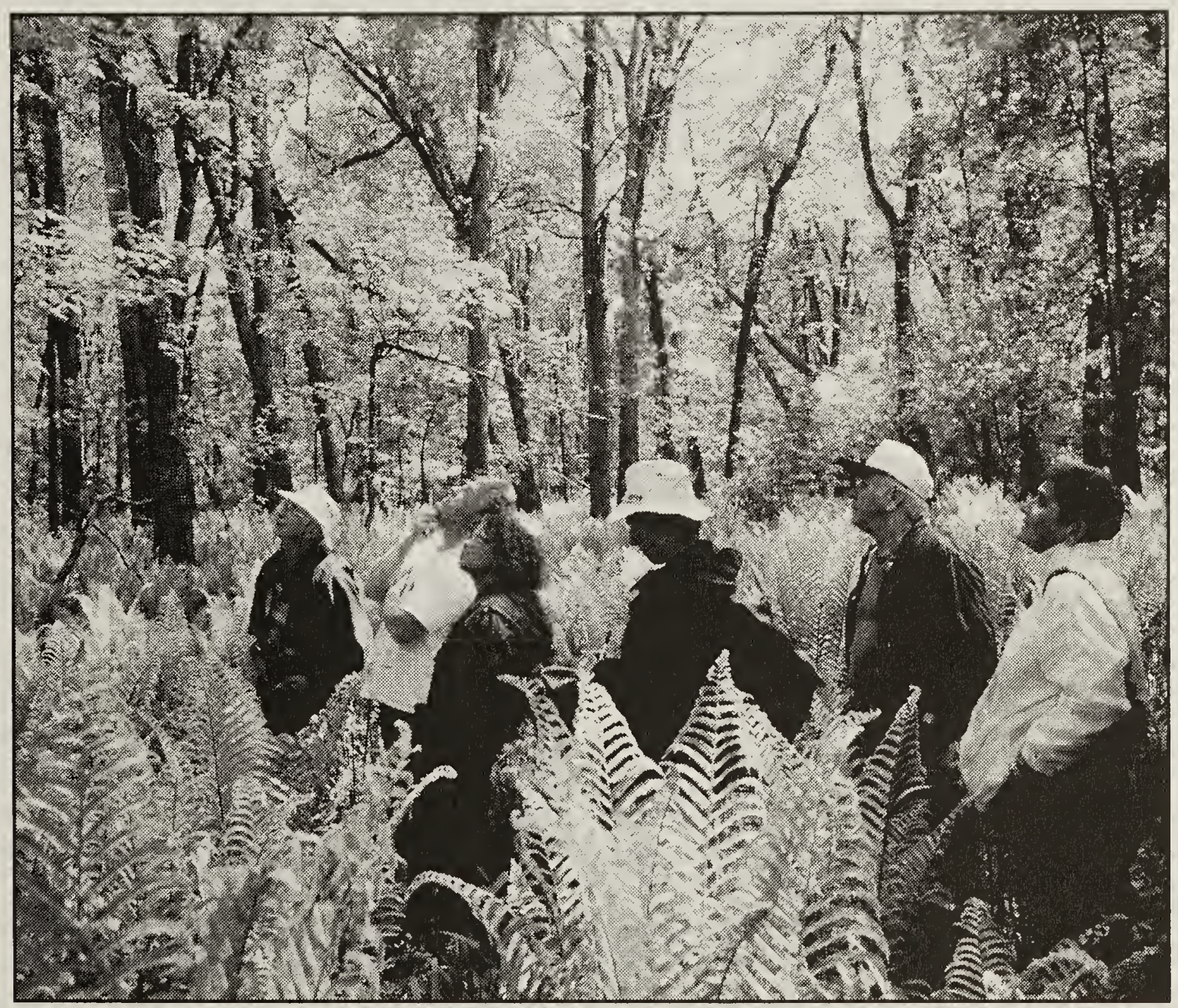

Figure 1. Garth Nelson leading a group in the Rendek Elm Forest Nature Sanctuary. Mr. Rendek, second from right. 
In December 1998, Vern Harms and Les Baker published a list of the vascular plant species found at the Rendek Elm Forest Nature Sanctuary owned by Nature Saskatchewan. 'They based this list on a collecting trip made to the area on 9 July 1981. In the article, Harms and Baker stated that "a more intensive floristic inventory, continued over the growing season, would no doubt increase the species' list" for the sanctuary.

The Rendek Elm Forest is about 25 $\mathrm{km}$ northeast of Hudson Bay at the confluence of the Red Deer River and Smoking Tent Creek. The forest consists of American Elms (UImus americana) and Manitoba Maple (Acer negundo) with a few other trees present in smaller numbers. The understory vegetation is unusually tall due to the high moisture level and rich soil found at this site; some Ostrich Ferns (Matteuccia struthiopteris) have leaves over 6 feet long! (Figure 1) Unfortunately, the elms in the forest are now threatened with Dutch Elm Disease. [Editors' Note: According to Richard Kerbes, President of S.O.S. Elms, Dutch Elm Disease was found in the Rendek Elm Forest in 1999 and two infected trees were removed in May 1999 to try to slow the spread of the disease moving into the area along the Red Deer River.]

Two plant collecting trips have been made to the area since the preliminary list was published. Diana Bizecki Robson visited the Rendek Elm Forest on13 June1998 with Garth Nelson, Ruth Englund and Phyllis Bordass while on a tour of Nature Saskatchewan's sanctuaries in the east central part of the province. Ten species of vascular plants not recorded by Harms and Baker were observed during this trip. On 30 May 1999 Vern and Ramona Harms observed and collected an additional 13 new species for the sanctuary. The total number of families is now 34 (up four) and the total number of species 75 (up 23). Three of the species found are exotics: Smooth Brome (Bromus inermis), Creeping Charlie (Glechoma hederacea) and Dandelion (Taraxacum officinale). One of the new finds collected on 30 May, 1999 was the rare Smooth Yellow Violet (Viola pubescens Ait. var. scabriuscula), ranked S1 by the Saskatchewan Conservation Data Centre and known from fewer than 5 locations in Saskatchewan. We felt that these new additions should be listed in Blue Jay. The area has still not yet been explored in late summer and this would be a good time to look for additional species.

\section{SPECIES LIST}

Asteraceae (Aster Family)

Taraxacum officinale Weber; DANDELION. Roadside.

\section{Caprifoliaceae (Honeysuckle Family) \\ Lonicera dioica L.; TWINING HONEYSUCKLE. Woods.}

Caryophyllaceae (Pink Family) Moehringia lateriflora (L.) Fenzl. [Arenaria lateriflora L.]. GROVE SANDWORT. Woods

Cornaceae (Dogwood Family) Cornus stolonifera Michx. [C. alba auct. p.p. non L.]; RED-OSIER DOGWOOD. Woods.

\section{Cyperaceae (Sedge Family)}

Carex peckii E.C. Howe.; PECK'S SEDGE. Woods.

Carex sprengelii Dewey; SPRENGEL'S SEDGE. Woods.

\section{Fabaceae (Pea Family)}

Lathyrus venosus Muhl.; WILD PEAVINE. Woods. 
Grossulariaceae (Currant Family)

Ribes oxyacanthoides L.; NORTHERN

GOOSEBERRY. Woods.

\section{Lamiaceae (Mint Family)}

Glechoma hederacea L.; CREEPING

CHARLIE. Roadside.

\section{Liliaceae (Lily Family)}

Disporum trachycarpum (S. Wats.) B. \& H.; FAIRYBELLS. Woods

Maianthemum canadense Desf. var. interius Fern.; TWO-LEAVED

SOLOMON'S-SEAL. Woods.

\section{Oleaceae (Olive Family)}

Fraxinus pennsylvanica Marsh.; GREEN ASH. Woods.

\section{Onagraceae (Evening-primrose}

\section{Family)}

Epilobium angustifolium L.;

FIREWEED. Bank.

\section{Poaceae (Grass Family)}

Bromus inermis Leyss.; SMOOTH BROME. Roadside.

\section{Ranunculaceae (Crowfoot Family)}

Thalictrum venulosum Trel.; VEINY MEADOW-RUE. Woods.
Rhamnaceae (Buckthorn Family)

Rhamnus alnifolia L'Her; ALDER-

LEAVED BUCKTHORN. Woods.

\section{Rosaceae (Rose Family)}

Amelanchier alnifolia Nutt.;

SASKATOON. Woods.

Rubus pubescens Raf.; DEWBERRY.

Woods.

Rosa woodsii Lindl.; WOOD'S ROSE.

Woods.

Rubus idaeus L.; CANADA

RASPBERRY. Woods.

Potentilla anserina L.; SILVERWEED.

Bank.

Salicaceae (Willow Family)

Populus balsamifera L.; BALSAM OR

BLACK POPLAR. Woods.

\section{Violaceae (Violet Family)}

Viola pubescens Ait. var. scabriuscula Schw.; SMOOTH YELLOW VIOLET.

Woods. (S1; THR)

1. Harms, Vern and Les Baker. 1998. A preliminary floral list for the Rendek Elm Forest Nature Sanctuary in east-central Saskatchewan. Blue Jay 56 (4): 213-215

\section{FOUR INTRODUCED SPECIES NEW TO SASKATCHEWAN FROM THE 1990s}

JOHN H. HUDSON, 103 Richmond Crescent, Saskatoon SK, S7K 1A9

The plant records reported here have nothing in common with one another except that they are all introductions two weeds pure and simple, one forage grass, and one garden escape. There is a theme behind this - people write of the plague of exotics already in our flora, but in this age of world-wide transport, more exotics keep arriving.

One of the mere weeds is Senecio viscosus L., Stinking Groundsel, 